\title{
Evaluation of the history of caries and associated factors among quilombolas in Southeastern Brazil
}

\author{
Maria Cristina Almeida de Souza', Flávia Martão Flório² \\ ${ }^{1}$ Universidade Severino Sombra - USS, School of Dentistry, Department of Dental Public Health, Vassouras, RJ, Brazil \\ ${ }^{2}$ Faculdade São Leopoldo Mandic - SLMANDIC, Dental School and Research Center, Department of Dental Public Health, Campinas, SP, Brazil
}

\begin{abstract}
Aim: To evaluate caries prevalence and associated factors in Quilombola communities. Methods: The study involved a cross-sectional study with Quilombola communities in Southeastern Brazil, in 2011. The data were collected by interviews and clinical examination. The sample was checked for caries prevalence (dmft and DMFT index) by one trained and calibrated dentist, reaching acceptable levels of agreement for data collection. The data were analyzed using descriptive statistics and frequency distribution. The significance of the associations between the dependent variable (dental caries) and the independent variables was verified using chi-squared or Fisher's Exact tests. Variables with a $p$-value $<0.25$ were tested using multiple logistic regression models in order to keep those with a pd" 0.05 value. Odds ratios were estimated using regression models and $95 \%$ confidence intervals. The population consisted of 171 quilombolas ( $97 \%$ of total). Results: Mean dmft value was 1.91 ( \pm $2.71)$ at age d"5 years and mean DMFT values were $1.20( \pm 1.49), 3.50( \pm 2.23), 10.3( \pm 4.79)$, $22.9( \pm 5.37), 22.8( \pm 4.12)$, respectively in the age groups: $6-12,13-18,19-34,35-59$ years and 60 years or older. Age less than 5 years ( $p$-value 0.014 ), own perception of oral health ( $p$-value 0.040 ) and education level were variables associated with dental caries in permanent teeth and need for treatment in the deciduous dentition. Conclusions: High prevalence of dental caries indicates the need for restructuring the dental care provided to the quilombolas.
\end{abstract}

Keywords: dental caries; cross-sectional studies; ethnic groups; oral health; vulnerable populations.

Received for publication: May 28, 2014 Accepted: August 08, 2014

Correspondence to:

Maria Cristina Almeida de Souza Rua Aldo Cavalli, no. 169 - Centro, 27.700-000

Vassouras, RJ, Brasil Phone: +55 24981149582 E-mail: mcas.souza@uol.com.br

\section{Introduction}

Despite data from the most recent census reporting that the majority of the Brazilian population is of black origin, understood as a combination of those self-declared black and mixed races ${ }^{1}$, the inequality of opportunities between white and black people are evident by the contrasting life conditions. In $2008,8.5 \%$ of white women and $10.1 \%$ of white men reported never have gone to a dentist, whilst among black people those percentages were $12.6 \%$ and $15.4 \%$, respectively ${ }^{2}$. Inequalities are also reflected in the living conditions of black people living in maroon communities, recognized by the Palmares Cultural Foundation ${ }^{3}$ as a social group with a distinctive ethnic identity from the rest of the community. Quilombola communities were lawfully recognized by the Decree $4.887 / 2003^{4}$, as "racial-ethnic groups, according to the criterion of self-declaration of black ancestry, with historical background, with specific territorial relations". Planning 
public health policies towards the quilombolas is fundamental to change their situation of vulnerability and to provide a follow-up of their health condition which may allow for the identification of the most prevalent oral diseases.

The results of this study, which outlined the epidemiological oral profile of the quilombolas in southeastern Brazil, revealed their precarious oral condition and the difficulties in accessing dental care. In the Kalunga community, a quilombola group ${ }^{5}$, the prevalence of dental caries was $65.2 \%$ among individuals aged between 1 and 14 years, whereas for those over 20 years of age, this percentage increased to $92.9 \%$. High caries prevalence was also estimated among the quilombolas from the Patioba community: decayed, missing and filled teeth index (DMFT) of 6.0 at 12 years of age ${ }^{6}$.

In view of the scarce data regarding the oral condition of the quilombolas, the aim of the present study was to establish the prevalence of dental caries and associated factors among quilombolas in southeastern Brazil in 2011.

\section{Material and methods}

This study was approved by the Ethics Committee of the Sao Leopoldo Mandic Dental School (Process n ${ }^{\circ}$ 2011/0111). It also fulfilled the requirements of the Declaration of Helsinki and the recommendations of Resolution 196/96 by the National Health Council of Brazil and has no conflict of interests.

In 2011, a cross-sectional study was conducted on the quilombola communities of Sao Jose da Serra e Santana, situated at the municipalities of Valença and Quatis, respectively, in the state of Rio de Janeiro, in southeastern Brazil. These communities are certified by the Palmares Cultural Foundation ${ }^{3}$ as remaining quilombo communities. The inclusion criteria were: being of African descent, reside at the quilombo, agree to sign the specific Informed Consent Form (ICF) and agree with the completion of clinical examination and with the interview. One hundred and seventy one (171) of 176 quilombolas fulfilled the inclusion criteria and took part in this study, where 23 individuals were 5 years or younger, 32 were between 6 and 12 years of age, 18 aged between 13 and 18 years, 42 between 19 and 34 years, 37 aged between 35 and 59 years and 19 individuals older than 60 years. The interviews and oral examinations were performed at the individuals' homes under natural light using a dental mirror, by a single appropriately calibrated dentist (coefficient of diagnostic agreement Kappa $=0.91$ ).

The assessment of the oral condition followed the diagnostic criteria for dental caries and treatment recommended by the World Health Organization (WHO) ${ }^{7}$ for oral health surveys. The identification of caries-associated factors was achieved using the SBBrasil 2010 Survey questionnaire ${ }^{8}$, divided into three parts: a) socioeconomic characterization of the family; b) education level, oral disease morbidity and use of dental services; c) self-perception and impact of oral health on quality of life.

The data were analyzed using descriptive statistics and frequency distribution. The significance of the associations between the dependent variable (dental caries) and the independent variables was verified using Chi-squared or Fisher's exact tests. Variables with a $\mathrm{p}<0.25$ value were tested using multiple logistic regression models in order to keep those with $\mathrm{p} \leq 0.05$ value. Odds ratios were estimated using regression models and $95 \%$ confidence intervals.

\section{Results}

Socioeconomic characterization revealed that the most observed condition was a domicile occupied by 3 inhabitants. Four years of school education or fewer were reported by $57 \%$ of the quilombolas. Data on oral morbidity and use of dental services revealed that $63.2 \%$ of the quilombolas did not have toothache in the 6 months prior to the survey, $68.5 \%$ consulted a dental surgeon at least once in their lives, mainly in the public service $(57.9 \%)$ and the need for treatment was the most common reason $(25.1 \%)$. The service provided at the time was considered good by $21.6 \%$ of the quilombolas. Regarding self-perception and impact on oral health, $28.1 \%$ reported to be satisfied with their teeth or mouth, $49.1 \%$ did not think they needed dentures or change their dentures; and $44.4 \%$ already had pain or difficulty eating because of their teeth or toothache when drinking cold or hot liquids; $36.8 \%$ of the participants had experienced discomfort from their teeth when brushing, leaving $11.1 \%$ of them irritated. The quilombolas experienced impacts on their lives because of their oral conditions: $1.8 \%$ stopped having fun, $7.6 \%$ reported difficulty speaking, and $10.5 \%$ mentioned embarrassment when smiling or speaking. Respectively, $95.9 \%$ and $81.9 \%$ of the quilombolas did not miss work or had less sleep because of their teeth.

The mean dmft in the total population sample was $3.3( \pm 3.9)$ and the mean DMFT was 13.1( \pm 10.8$)$. In terms of age group, the mean dmft was $1.9( \pm 2.7)$ in the group aged 5 years or younger and the DMFT was $1.2( \pm 1.5), 3.5( \pm 2.2), 10.3( \pm 4.8), 22.9$ $( \pm 5.4), 22.8( \pm 4.1)$, respectively in the age groups: 6 to 12,13 to 18,19 to 34,35 to 59 years and 60 years or older (Table 1 ). There was an expressive influence of the component decayed on the DMFT up to the age of 34 years and, from this age on the component lost was the predominant. Caries-free individuals were $28.1 \%$ in the 6 to 12 years old group. This percentage decreased to $11.1 \%$ and to $4.8 \%$ between the quilombolas with 13 to 18 -year old and those aged 19 to 34 years, respectively. In the groups aged 35 to 59 years and older than 60 years, no caries-free individuals were detected. Only $21 \%$ of the subjects in the survey required no dental treatment.

Tables 2 and 3 show the bivariate analyses between the independent variables and the DMFT index dichotomized by the value of the median (median $=11)$. A significant association was observed between DMFT both to age $(p<0.001)$ as well as to the treatment need $(\mathrm{p}<0.001)$. Among the quilombolas that did not wear maxillary dentures $(p=0.001)$ and did not require maxillary or mandibular dentures $(\mathrm{p}<0.001)$ there was a lower frequency of people with high DMFT $(\geq 11)$. The bivariate analysis of the DMFT in terms of self-perception and impact on oral health (Table 3 ), revealed that the prevalence of caries was high in people who were dissatisfied with their teeth or with their mouth $(\mathrm{p}<0.001)$, between those who thought they needed full dentures, that needed their dentures replaced $(\mathrm{p}<0.007)$, those who had difficulty eating or had toothache when drinking $(p=0.005)$, those who reported discomfort when brushing their teeth $(p=0.002)$, those who felt 
Table 1. Mean dmft/DMFT values and relative frequency of the components decayed, missing/extracted and filled by age group.

\begin{tabular}{|c|c|c|c|c|c|c|c|}
\hline \multirow[b]{2}{*}{$\begin{array}{l}\text { Age } \\
\text { group } \\
\text { (years) }\end{array}$} & \multirow[b]{2}{*}{$\begin{array}{c}\text { dmftJDMFT } \\
\text { (mean } \pm \text { standard } \\
\text { deviation) }\end{array}$} & \multicolumn{2}{|c|}{ Decayed } & \multicolumn{2}{|c|}{ Extracted/Missing } & \multicolumn{2}{|c|}{ Filled } \\
\hline & & 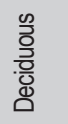 & 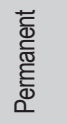 & 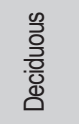 & 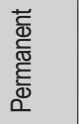 & $\begin{array}{l}\text { 오 } \\
\text { 흥 } \\
\text { 이 }\end{array}$ & 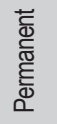 \\
\hline $\begin{array}{c}\leq 5 \\
(n=23)\end{array}$ & $1.9 \pm 2.7 /-$ & 92.8 & - & 0.0 & - & 7.1 & - \\
\hline $\begin{array}{l}6 \text { to } 12 \\
(n=32)\end{array}$ & $4.8 \pm 4.4 / 1.2 \pm 1.5$ & 50.0 & 80.0 & 25.0 & 5.00 & 25.0 & 15.0 \\
\hline $\begin{array}{l}13 \text { to } 18 \\
(n=18)\end{array}$ & $-/ 3.5 \pm 2.2$ & 2.8 & 48.1 & 48.5 & 22.2 & 48.5 & 29.6 \\
\hline $\begin{array}{l}19 \text { to } 34 \\
(n=42)\end{array}$ & $-/ 10.3 \pm 4.8$ & - & 51.9 & - & 20.9 & - & 27.1 \\
\hline $\begin{array}{l}35 \text { to } 59 \\
(n=37)\end{array}$ & $-/ 22.9 \pm 5.4$ & - & 32.6 & - & 62.9 & - & 4.5 \\
\hline $\begin{array}{c}\geq 60 \\
(n=19)\end{array}$ & $-/ 28.8 \pm 4.1$ & - & 31.2 & - & 59.3 & - & 9.3 \\
\hline
\end{tabular}

Table 2. Bivariate analysis among the independent variables and the DMFT index.

\begin{tabular}{|c|c|c|c|}
\hline Variable & Category & $\begin{array}{l}\text { DMFT } \geq 11 \\
\text { Frequency (\%) }\end{array}$ & p-value \\
\hline \multirow[t]{6}{*}{ Age } & $\leq 5$ years & - & $<0.001$ \\
\hline & 6 to 12 years & $0(0.0 \%)$ & \\
\hline & 13 to 18 years & $0(0.0 \%)$ & \\
\hline & 19 to 34 years & $23(54.8 \%)$ & \\
\hline & 35 to 59 years & $37(100.0 \%)$ & \\
\hline & $\geq 60$ years & $19(100.0 \%)$ & \\
\hline \multirow[t]{5}{*}{ Use of a maxillary denture } & None & $59(67.8 \%)$ & 0.001 \\
\hline & Partial denture & $3(100.0 \%)$ & \\
\hline & Fixed and removable prostheses & $1(100.0 \%)$ & \\
\hline & Complete denture & $16(100.0 \%)$ & \\
\hline & No information & - & \\
\hline \multirow[t]{4}{*}{ Use of a mandibular denture } & None & $70(71.4 \%)$ & 0.187 \\
\hline & Partial denture & $1(100.0 \%)$ & \\
\hline & Complete denture & $8(100.0 \%)$ & \\
\hline & No information & - & \\
\hline \multirow[t]{6}{*}{ Need for a maxillary denture } & No need & $19(43.2 \%)$ & $<0.001$ \\
\hline & Single unit denture & $7(77.8 \%)$ & \\
\hline & More than one unit & $6(100.0 \%)$ & \\
\hline & Mixture of dentures & $30(96.8 \%)$ & \\
\hline & Complete denture & $17(100.0 \%)$ & \\
\hline & No information & & \\
\hline \multirow[t]{6}{*}{ Need for a mandibular denture } & No need & $10(41.7 \%)$ & $<0.001$ \\
\hline & Single-unit denture & $4(40.0 \%)$ & \\
\hline & Multiple-unit denture & $6(60.0 \%)$ & \\
\hline & Mixture of dentures & $44(91.7 \%)$ & \\
\hline & Complete denture & $15(100.0 \%)$ & \\
\hline & No information & & \\
\hline \multirow[t]{6}{*}{ Treatment need } & Endodontics & $5(33.3 \%)$ & $<0.001$ \\
\hline & Extraction & $34(70.8 \%)$ & \\
\hline & Non-invasive & $0(0.0 \%)$ & \\
\hline & None & $8(36.4 \%)$ & \\
\hline & Denture & $9(100.0 \%)$ & \\
\hline & Restoration & $23(44.2 \%)$ & \\
\hline
\end{tabular}


Table 3. Bivariate analysis of DMFT as self-perception and impact on oral health.

\begin{tabular}{|c|c|c|c|}
\hline Variable & Category & $\frac{\text { DMFT }>11}{\text { Frequency }(\%)}$ & $p$-value \\
\hline \multirow[t]{5}{*}{ In relation to your teeth/mouth, you are: } & $\begin{array}{l}\text { Very satisfied } \\
\text { Satisfied }\end{array}$ & $\begin{array}{c}1(7.1 \%) \\
14(35.0 \%)\end{array}$ & \multirow{5}{*}{$<0.001$} \\
\hline & Neither satisfied nor & $27(57.4 \%)$ & \\
\hline & dissatisfied & & \\
\hline & Dissatisfied & $30(76.9 \%)$ & \\
\hline & Very dissatisfied & $5(100.0 \%)$ & \\
\hline \multirow{2}{*}{$\begin{array}{l}\text { Consider the need for the use of a full } \\
\text { denture or changing the one currently in use }\end{array}$} & No & $54(65.1 \%)$ & \multirow[t]{2}{*}{0.007} \\
\hline & Yes & $24(100.0 \%)$ & \\
\hline \multirow{2}{*}{$\begin{array}{l}\text { You had difficulty eating or toothache } \\
\text { when drinking cold or hot liquids }\end{array}$} & No & $28(38.9 \%)$ & \multirow[t]{2}{*}{0.005} \\
\hline & Yes & $50(67.6 \%)$ & \\
\hline \multirow[t]{2}{*}{ The teeth were uncomfortable during brushing } & No & $33(36.8 \%)$ & \multirow[t]{2}{*}{0.002} \\
\hline & Yes & $44(71.0 \%)$ & \\
\hline \multirow[t]{2}{*}{ The teeth made you angry or irritated } & No & $63(49.6 \%)$ & \multirow[t]{2}{*}{0.016} \\
\hline & Yes & $15(79.0 \%)$ & \\
\hline \multirow{2}{*}{$\begin{array}{l}\text { You did not go out, have fun, go to parties, } \\
\text { travelled, because of your teeth }\end{array}$} & No & $77(53.8 \%)$ & \multirow[t]{2}{*}{0.598} \\
\hline & Yes & $1(33.3 \%)$ & \\
\hline \multirow{2}{*}{$\begin{array}{l}\text { You had difficulty speaking } \\
\text { because of your teeth }\end{array}$} & No & $65(48.9 \%)$ & \multirow[t]{2}{*}{$<0.001$} \\
\hline & Yes & $13(100.0 \%)$ & \\
\hline \multirow{2}{*}{$\begin{array}{l}\text { Your teeth made you embarrassed } \\
\text { to laugh or speak }\end{array}$} & No & $60(46.9 \%)$ & \multirow[t]{2}{*}{$<0.001$} \\
\hline & Yes & $18(100.0 \%)$ & \\
\hline \multirow{2}{*}{$\begin{array}{l}\text { Your teeth interfered with your } \\
\text { studies/work or homework }\end{array}$} & No & $72(51.8 \%)$ & \multirow[t]{2}{*}{0.122} \\
\hline & Yes & $6(85.7 \%)$ & \\
\hline \multirow{2}{*}{$\begin{array}{l}\text { You were unable to sleep or slept } \\
\text { badly because of your teeth }\end{array}$} & No & $58(50.4 \%)$ & \multirow[t]{2}{*}{0.207} \\
\hline & Yes & $19(63.3 \%)$ & \\
\hline
\end{tabular}

irritated because of their teeth $(p=0.016)$, had speech difficulty $(\mathrm{p}<0.001)$, and those who felt shame to smile and to speak because of their teeth $(\mathrm{p}<0.001)$.

The multiple logistic regression model was set up using the variables with the highest significance. The final model is presented in Table 4 . The participants with less than 5 years of study in this survey had a 2.75 (95\% CI 1.22-13.79) higher chance having a high DMFT $(\geq 11)$; and those who thought they needed dental treatment had a $2.84(95 \%$ CI $1.05-7.72)$ higher chance of having a high DMFT $(\geq 11)(p=0.040)$. For the dependent variable $\mathrm{dmft}($ median $=2)$ a significant association was only detected with treatment need, as identified during clinical examination $(\mathrm{p}<0.001)$, where tooth extraction was the main treatment need.

\section{Discussion}

Many quilombola communities had no other basic needs warranted, especially in terms of access to better sanitation, housing, food and health, all of which are recognizably essential for an acceptable quality of life ${ }^{9}$. Despite the African descendents are majoritarian in Brazil, those residing in the remaining quilombos are the minority, who still fight for equality in terms of health and society in a perspective of emancipation ${ }^{10}$.
The relevance of this study is mainly related to the oral health in the quilombola communities, on which scientific publications are scarce, thus highlighting the pioneering application by the census methodology for data collection. The expressive number of individuals who accepted to take part in the study was credited to the influence of their religious leaders as well as to the constant presence of the examiner within the community. In that sense, the internal validity of the study was safeguarded.

Comparing the results of this study with others in literature was difficult due to lack of publications that used the same age groups in this study. In oral health surveys, the used index ages are generally those recommended by the $\mathrm{WHO}^{7}$, which were not possible in this study due to the low number of quilombolas who, during the development of this study, resided in the remaining quilombos: 81 and 95 individuals ${ }^{11}$ in the communities of Sao Jose da Serra, in Valença and in the community of Santana, at the municipality of Quatis, respectively; this was one of the limitations of this study, since the sample became quantitatively small. In order to minimize the bias resulting from sample size, it was decided to: a) abandon the individualized analysis of the remaining quilombos, especially after examining the data from the Brazilian Institute for Geography and Statistics ${ }^{12}$, which revealed very close similarities between the socioeconomic characteristics of the two communities; b) include all quilombolas in the study 
Table 4. Multiple logistic regression for DMFT.

\begin{tabular}{|c|c|c|c|c|c|}
\hline Variable & Category & $\frac{\mathrm{DMFT} \geq 11}{\text { Frequency }(\%)}$ & *OR adjusted & ${ }^{* *} \mathrm{Cl} 95 \%$ & $p$-value \\
\hline Number of & $<5$ years & 49 (67.1\%) & 2.75 & $1.22-13.79$ & 0.014 \\
\hline study years & $\geq 5$ years & $25(43.1 \%)$ & Reference & & \\
\hline Need for & No & $9(34.6 \%)$ & Reference & $1.05-7.72$ & 0.040 \\
\hline treatment & Yes & $66(63.5 \%)$ & 2.84 & & \\
\hline
\end{tabular}

*Odds ratio; * Confidence Interval 95\%.

in order to guarantee the internal validity. This decision generated peculiar age stratification, due to the inclusion of quilombolas aged between 1 and 104 years. Nevertheless, this classification was similar to that adopted by Soares et al. ${ }^{5}$, while studying the quilombola community of Kalunga.

The socioeconomic characterization of the population by this study allowed establishing that most domiciles were inhabited in a similar fashion as reported in the 2011 National Survey for Domicile Sample: 3 inhabitants ${ }^{13}$. Young adults were predominant in the remaining quilombos and the low number of quilombolas older than 60 years was in agreement with the report on the communities Kalunga ${ }^{5}(8.0 \%)$, Furnas do Dionísio ${ }^{14}(8.0 \%)$ (6.4\%), Caiana dos Crioulos ${ }^{15}(12.3 \%)$, Serra do Osso ${ }^{16}(5.8 \%)$. The family heads reported low levels of education, a known risk factor for the presence of caries, which helps to understand the severity of this problem among the quilombolas. $31.6 \%$ of the quilombolas mentioned they had spontaneous toothache, which was higher than the $24 \%$ reported by the Kalunga quilombolas 5 . Pain, as the reason for visiting a dentist, was mentioned by only $17 \%$ of the quilombolas, which was lower than reported by the remaining quilombolas from Santo Antônio do Guaporé9 ${ }^{9}$ This allowed concluding that the quilombolas choose elective dental treatment, facilitated by the presence of an oral health team in the establishment of health ${ }^{17}$. Similarly to the data collected from Brazilians interviewed by the 2011 National Survey for Domicile Sample ${ }^{13}$ and the quilombolas from the State of Rondônia, Brazil $(41.3 \%)^{9}$, the public health service was the main place for consultations for the quilombolas that participated of this study (57.9\%). Amongst the public oral health service users from this study, $21.6 \%$ considered it good, which was lower than the quilombolas from Santo Antônio do Guaporé9, where 44.8\% rated the service as good, and also lower than the participants from the SBBrasil 2010 survey $^{8}$, which highlights the need to restructure the service by the municipal public administration.

The distance to the health establishment was one of the difficulties faced by the quilombolas in the access to public health services, for being located in rural areas, separated from their nearest communities by unpaved roads, with little options of public transportation. Geographical isolation associated with low self-perception in terms of oral health may justify the fact that $32.2 \%$ of the subjects in this study reported having never seen a dentist in their lives, despite the recent and considerable government investments in oral health programs and including the fact that Brazil has one of the highest rates of dentists per capita ${ }^{18}$.

The subjects in this study were less irritated as a result of their teeth $(11.1 \%)$, when compared to Brazilians aged 35 to 44 years $(29.0 \%)$, under the same conditions as those participating in the 2010 SBBrasil survey $^{8}$. In terms of the perception with regard to the need for full dentures, $49.1 \%$ quilombolas felt it unnecessary to use full denture or to change the full denture they were using, despite reporting the use of prostheses for more than 30 years, which was similarly observed by Azenha et al. ${ }^{19}$, who reported the use of full dentures for much longer than the recommended time.

The estimated value of $\mathrm{dmft}$ in the $\leq 5$ years group was superior to that found by Prakash et al. ${ }^{20}$ in 8 to 48 months old children and similar to that found by Amaral et al. ${ }^{21}$. The dmft estimated among quilombolas in the 6-12-year-old group was 4.8 (SD 4.4), a value close to the one reported by Almeida et al. ${ }^{22}$ among preschool children aged 4 and 7 years in the state of Rondônia, Brazil $(\mathrm{dmft}=3.0)$. Prado et al. ${ }^{23}$ found a higher prevalence of caries in the primary dentition among 5-year-old children than that observed in the quilombola children participating in this study.

A reduction in dental caries in the deciduous dentition has been confirmed by national surveys ${ }^{8,24}$ and despite this decrease, children from low socioeconomic strata still present significant need for treatment ${ }^{25}$. The improvement in caries indicators was accompanied by polarization of dental caries in socioeconomically deprived individuals ${ }^{26}$, which helps understanding the pattern of caries of quilombola children, which does not concur with information that historically public dental health in Brazil prioritized the children enrolled in public schools ${ }^{18}$.

All the examined children study in a public institution, which, according to Almeida et al. ${ }^{22}$ and Melo et al. ${ }^{25}$, have a higher prevalence of caries as a result of parents with a low level of education and socioeconomic status, factors proven to be related to the presence and severity of dental caries. Several publications have shown declining trends in caries experience, thus many researchers studied the factors associated with this decline ${ }^{21}$. The presence of caries among the quilombola children is probably related to factors such as the ingestion of water without fluoride, the distance and transportation costs to the health unit, the low education level of the guardians, and the lack of preventive and restorative health actions by the oral health teams. These findings corroborate those by Antunes et al. ${ }^{27}$, who reported that black and mixed-race children, students from rural areas and public preschools present a significantly higher chance of having decayed deciduous teeth.

In the 6 to 12 years group, the component decayed represented $80.0 \%$ of the DMFT, whereas the component filled only represented $15 \%$ of the index, suggesting a lack of access by the quilombolas to oral health services, whereas amongst those aged between 13 and 18 years, the same prevalence for both the 
missing and filled components $(48.5 \%)$ was detected. It was observed that pre-adolescents and adolescents attended the dental service, probably because many no longer depended on their guardians to accompany them. Additionally, they value their physical appearance, which is directly related to their oral condition, therefore important in their social relationships. The estimated mean DMFT among the quilombolas older than 60 years $(28.8 \%)$ was similar to the elderly Brazilians in $2010^{8}$. Regarding the permanent and deciduous dentitions, it was observed that the mean DMFT values at 12 years of age among Brazilians have been decreasing. In 2003 it was estimated at 2.8 and in 2010, at 2.0 (Brazil, 2011) ${ }^{8}$. In the city of Rio de Janeiro, a DMFT of 1.4 was detected in 12-year-olds, while in the Southeastern countryside region, where the studied African descendents resided, the value was 1.8. Tobias et al. ${ }^{28}$ reported a mean DMFT of 3.7 in children from Amazonas, Brazil, which was similar to the quilombolas aged between 13 and 18 years, whose DMFT was 3.5. Amongst the studied quilombolas, the DMFT in the age group 6 to 12 years was estimated at 1.2 , which was below the national mean, capitals and State countrysides average, as verified by SBBrasil $2010^{8}$. Among the studied quilombolas, $63.0 \%$ of the children aged 5 years or younger were free of caries $(\mathrm{dmft}=0)$, close to the $54.1 \%$ of children aged between 1 and 5 years found in the Kalunga community ${ }^{5}$ under the same conditions. However, it was higher than that reported in the SBBrasil 2010 survey $^{8}$. The probable reason for the considerable percentage of quilombola children free of caries aged 5 years or younger was the fact that the survey included children of low age and, therefore have few teeth. Whereas between 6 and 12 years of age, this value dropped to $28.1 \%$, and between 13 and 18 years $11.1 \%$ of the children had a zero dmft, which confirms that prevalence of caries increases with age. Data from the SBBrasil 2010 survey $^{8}$ showed that at $5,12,15$ to 19,34 to 45 , and 65 to 74 years, the percentage of people free of caries was $46.6 \%, 43.5 \%$, $23.9 \%, 0.9 \%$ and $0.2 \%$, respectively.

The DMFT in the group aged 19 to 34 years was estimated at 10.3 (SD 4.8), which was lower than the DMFT of adults aged between 35 and 44 years (16.7) in Brazil 2010. The DMFT of quilombolas aged between 35 and 39 years was 22.9 , with a predominance of the component missing $(62.9 \%)$ and only $4.5 \%$ of the index was represented by the component filled. In the group aged 60 years or older, the DMFT was 28.8, where $59.3 \%$ of the index comprised the component missing. The mean DMFT value (13.1) of the total sample was similar to that encountered by Araújo ${ }^{29}$, who reported a value of 11.9 in his study population, mostly black (89.2\%), seeking dental treatment at the Para Federal University in Brazil.

In conclusion, oral health problems are prevalent among the quilombolas. The prevalence of dental caries was demonstrated to be associated with factors such as education and self-perception of oral health in the permanent dentition and need for treatment in the deciduous dentition. The evidence that the service provided to the community was not sufficient to meet their dental needs highlights the importance of restructuring the actions in disease prevention and health promotion and restoration.

\section{References}

1. Brazilian Institute of Geography and Statistics. 2010 Census: overall results of the sample. Rio de Janeiro: IBGE; 2010.

2. Paixão M, Rossetto I, Montovanele F, Carvano LM. Annual Report of Racial Inequality in Brazil; 2009 to 2010. LAESER. Rio de Janeiro: Federal University of Rio de Janeiro; 2010.

3. Palmares Cultural Foundation. Quilombo communities [Internet]. 2011 [cited 2012 Feb 02]. Available from: http://www.palmares.gov.br/ quilombola/ \#; 2000

4. Brazil. Presidency of the Republic. Decree 4887, 2003 November 20. Regulates the procedure for identification, recognition, delimitation, demarcation and granting of tenure of lands occupied by remnants of quilombo mentioned in art. 68 of the Temporary Constitutional Provisions. Official Gazette of the Federative Republic of Brazil, Brasília (DF), 2003. [Internet]. 2011. [cited 2012 Feb 02]. Available from: http:// www.planalto.gov.br/ccivil_03/decreto/2003/d4887.htm

5. Soares EF, Freire MCM, Araújo AC. Kalunga Community - GO, Brazil: first report on caries experience and oral health behaviour. Rev Paul Odontol. 2002; 24: 21-5.

6. Rose JAA. Epidemiology of oral health in quilombola community Patioba Sergipe-Brazil [dissertation]. Aracaju (SE): University of Tiradentes; 2012.

7. World Health Organization. Oral health surveys: basic methods. 4th ed. São Paulo: Santos; 1999.

8. Brazil. Ministry of Health. National oral health survey 2010. Main Results. Brazilia: Ministry of Health, 2011. Available from: http://189.28.128.100/ dab/docs/geral/projeto_sb2010_relatorio_final.pdf.

9. Silva MEA, Rosa PCF, Neves ACC, Rode SM. Prosthetics needs of the Quilombola Population of Santo Antonio Guaporé, Rondônia. Braz Dent Sci. 2011; 14: 62-6.

10. Marques AS, Caldeira AP, Souza LR, Zucchi P, Cardoso WDA. The population slave descendents in the North of Minas Gerais: invisibility, inequalities, and denial of access to the public health system. Bol Inst Saude. 2010; 12: 154-61.

11. BRAZIL. Ministry of Health Department of Health Care, Department of Primary Care. Primary care information system: indicators 2011. Brasilia: Ministry of Health; 2011.

12. Brazilian Institute of Geography and Statistics [Internet]. 2010 [cited 2013 May 24]. Available from: http://cidades.ibge.gov.br/xtras/home.php

13. National Household Sample Survey 2011. [Internet]. 2012 [cited 2012 Sept 24]. Available from: http://www.ibge.gov.br/home/estatistica/ populacao/trabalhoerendimento/pnad2011/

14. Gibran TM. Quality of life and oral esthetic in the remanscent community of "Quilombo de Furnas do Dionísio, Mato Grosso do Sul" [master's dissertation]. Campo Grande, MS: Dom Bosco Catholic University; 2006.

15. Silva JAN. Sanitary and health conditions at Caiana of Crioulos, a quilombo community in the State of Paraíba. Saude Soc. 2007; 16: $111-24$.

16. Araújo MAR, Santana MC, Azevedo Filho RD. Epidemiological profile of the quilombo Sierra Bone-Pernambuco [monography]. Recife: Center of Research Ageu Magalhães; 2009.

17. National Registry of Health [Internet]. 2011 [cited 2013 May 23]. Available from: http://cnes.datasus.gov.br/Lista_Tot_Equipes.asp.

18. Peres KG, Peres MA, Boing AF, Bertoldi AD, Bastos JL, Barros AJB Reduction of social inequalities in utilization of dental care in Brazil from 1998 to 2008. Rev Saude Publica. 2012; 46: 1-8

19. Azenha MR, Lacerda AS, Handem RH, Ferreira EGP. Epidemiologic analysis of health buccal condition in elderly population. Int Dent $\mathrm{J}$. 2011; 10: 228-33.

20. Prakash P, Subramaniam P, Durgesh BH, Konde S. Prevalence of early childhood caries and associated risk factors in preschool children of urban Bangalore, India: a cross-sectional study. Eur J Dent. 2012; 6: 141-52. 
21. Amaral RC, Batista MJ, Meirelles MPMR, Cypriano S, Sousa MLR. Dental caries trends among preschool children in Indaiatuba, SP, Brazil. Braz J Oral Sci. 2014. 13:1-5.

22. Almeida DL, Nascimento DOR, Rocha ND, Dias AGA, Castro RFM, Closs OS. Oral health assessment of preschool children aged 4 to 7 years attending a philanthropic daycare center. RGO. 2011; 59: 271-5.

23. Prado SU, Bastos JRM, Mestriner JW. Epidemiology of carious lesions in the primary dentition of pre-school children of Brodowski-SP. Rev ABO Nac. 2003; 11: 343-9.

24. Brazil. Ministry of Health. National oral health survey 2010. Main Results. Brasilia: Ministry of Health; 2011.

25. Melo MMDC, Souza WV, Lima MLC, Braga C. Factors associated with dental caries in preschoolers in Recife, Pernambuco State, Brazil. Cad Saude Publica. 2011; 27: 471-85.

26. Baldani MH, Brito WH, Lawder JAC, Mendes YBE, Silva FFM, Antunes JLF. Individual determinants of dental care utilization among low-income adult and elderly individuals. Rev Bras Epidemiol. 2010; 13: 150-62.

27. Antunes JLF, Peres MA, Mello TRC. Individual and contextual determinants of dental treatment needs of children with primary dentition in Brazil. Cienc Saude Col. 2006; 11: 79-87.

28. Tobias R, Parente RCP, Rebelo MAB. Prevalence of dental caries and treatment needs among 12-year-old children in a small-sized municipality in the Amazon region. Rev Bras Epidemiol. 2008; 11: 608-18.

29. Araújo MVA. Study of oral health conditions and treatment needs of patients of the dentistry course at the Federal University of Para [dissertation]. São Paulo: University of São Paulo; 2003. 